\title{
Using Recycled Construction and Demolition Waste Products: A Review of Stakeholders' Perceptions, Decisions, and Motivations
}

\author{
Salman Shooshtarian ${ }^{1, *(\mathbb{D})}$, Savindi Caldera ${ }^{2}$, , Tayyab $\operatorname{Maqsood~}^{1}$ and Tim Ryley ${ }^{3}(\mathbb{C}$ \\ 1 School of Property, Construction and Project Management, RMIT University, Melbourne 3000, Australia; \\ tayyab.maqsood@rmit.edu.au \\ 2 Cities Research Institute, Griffith University, Brisbane 4111, Australia; s.caldera@griffith.edu.au \\ 3 School of Engineering and Built Environment, Griffith University, Brisbane 4111, Australia; \\ t.ryley@griffith.edu.au \\ * Correspondence: salman.shooshtarian@rmit.edu.au; Tel.: +61-426-99-1363
}

Received: 9 October 2020; Accepted: 23 November 2020; Published: 24 November 2020

\begin{abstract}
While the increasing rate of urbanisation is a critical concern for socio-environmental reasons, this also leads to more extraction of natural raw materials and the generation of significant quantities of construction and demolition $(C \& D)$ waste. Although the use of recycled C\&D waste products is technically feasible and regulated, and positive application examples are evident, it is still unclear how to engage key stakeholders to leverage this opportunity in construction projects. Previous research has shown that there is some level of resistance to the reuse of recycled C\&D waste products in construction projects. This highlights a critical need to identify the roles of key stakeholders and the barriers they face when using recycled $C \& D$ materials. This paper therefore investigates the type of stakeholders influencing the use of recycled C\&D waste products and the main factors affecting stakeholders' decisions to use recycled C\&D waste products through a systematic literature review. The authors present an emergent enablers and barriers for recycled C\&D waste products model and provide commentary on how stakeholders' perceptions, decision and behaviour influence the use of recycled C\&D waste products. The authors also contribute to the body of knowledge with insights into the factors that various stakeholders believe influence the market for recycled C\&D waste products and provides a reference point for authorities to consider these behavioural insights for policy reform.
\end{abstract}

Keywords: acceptance; waste products; stakeholder; barrier; recycled waste market; circular economy

\section{Introduction}

While the increasing rate of urbanisation is a critical concern for environmental and social reasons, this also causes a rapid increase in construction activities around the world [1]. This trend presents challenges in terms of more extraction of natural raw materials and the generation of a substantial quantity of construction and demolition (C\&D) waste [2]. Construction activities consume more raw materials by weight than any other industrial sector, nearly $32 \%$ of the world's resources, including $12 \%$ of water and up to $40 \%$ of energy. Approximately $40 \%$ of all raw materials extracted from the Earth and $25 \%$ of virgin wood are used for construction [3]. Furthermore, due to the continuous rate of waste generation and the nature of the industry, it is a challenging task to achieve a zero-waste [4].

As resources are increasingly scarce, opportunities to create circular resource flows-otherwise known as the circular economy-cannot be overlooked [5]. This means more efforts should be directed towards keeping the resources in the loop for a longer period through reusing repairing and recycling [6,7]. While cleaner techniques for selective demolition are used to reduce generation 
of waste at source [8], there should be more focus on waste minimisation during the design stage. 'Modular design', 'waste reduction investment', 'economic incentives' are identified as critical factors for reducing waste at design stage [9].

While waste recovery is a reliable method to manage $C \& D$ waste [10] recycling has been identified as one targeted approach to address diminishing resources and associated pollutions, by reducing the burden on natural resources [11]. The use of recycled materials in the construction industry assists with a reduction in the need for raw material extraction, which results in material depletion and other environmental problems [12]. Some European countries have taken the lead in such sustainable practices and have been using recycled concrete aggregates since the late 1970s [13]. Even though the use of recycled C\&D waste products is technically feasible and regulated, and positive application examples are evident, it is not yet widely considered in most construction projects. Research has shown that there is a resistance to reuse and the use of recycled C\&D waste products in construction projects [14]. Stakeholders still tend to use conventional materials for low and high-grade applications. Thus, there is a critical need for a paradigm shift from business as usual (i.e., use of conventional materials) to use more of recycled materials.

Analysis of previous literature demonstrates several benefits for using recycled C\&D waste products in the construction industry, namely: reduced construction costs; avoiding landfill tax and illegal dumping; reduction in energy consumption, greenhouse gas (GHG) emissions and other pollutants; conservation/preservation of precious land areas; the extension of the lifespan of landfills; and job creation $[1,4,15,16]$. Bolden et al. [16] state that the three top reasons for using recycled materials among US construction companies are waste disposal reduction, quality (with additive materials compared to raw materials) and reduced economic and environmental costs.

Advanced technologies and developing new applications have facilitated costs savings in recycled $C \& D$ waste products. This cost-saving can be categorised as social, environmental, or economic and are better for the bottom line, people and planet. While evidence for economic cost savings on recycled materials is being increasingly revealed $[17,18]$ previous studies [19] illustrate that the benefits are site-specific and hinge on multiple factors including the type of material, building elements, transport distances, and economic and political contexts. Tax on landfilling is an effective way to discourage waste disposal and encourage further recovery activities. However, it is reported that it could be a major hurdle to construction companies reducing their costs to the extent that leads to an increase in housing affordability [20]. It is also noted that, in some situations, landfill levies generate unintended outcomes such as illegal dumping and stockpiling [21]. Waste recycling is the best method to reduce or eliminate costs associated with the use of a landfill levy.

It is reported that recycled aggregate can have lower embodied energy in addition to reduced transport emissions, especially where recycled materials are reused in close proximity to the site of re-processing [22]. A study in Japan estimates that a typical residential building constructed of recycled materials would save a minimum of $10 \%$ of energy demand [23]. Furthermore, Japan is also adopting advanced technologies to improve the quality of recycled aggregate, so that it can be used for high-grade secondary (i.e.,: concrete) applications [24].

Hossain et al. [25] showed that, compared with natural coarse aggregates, recycled coarse aggregates leads to a reduction of up to $65 \%$ GHG emissions with savings of up to $58 \%$ non-renewable energy consumption and the same was observed for producing recycled fine aggregates from C\&D waste. In Australia, the energy consumption and the resulting GHG emissions from the recycling of aggregate have been calculated to be around $4 \mathrm{~kg} \mathrm{CO}_{2}$ per ton, representing $22-46 \%$ fewer emissions than an equivalent conventional quarry product [26]. Despite these results, there are other studies that could not verify the positive recycled C\&D waste products carbon footprint [27] due to various reasons including lower structural performance, which needs to be addressed using additional reinforcements.

The limitations to the use of recycled C\&D waste products in construction projects are manifold. The previous literature indicated that the major reasons are uncertainty about quality, lack of information, cost complications and encumbering regulations. One study in Australia [28] reports that the 
interviewees believed that some reusable and recycled materials could not easily be used as new materials and sometimes there is no guarantee of their quality. It is argued that proper proportion design and suitable treatment technique can address the issues pertaining to the potential poor quality [2]. A lack of information about technical properties and environmental impacts of recycled C\&D waste products, clear quality standards, governmental support and appropriate located recycling facilities, plus the "waste" image of recycled C\&D waste products and the availability of landfill as a cheap option for $C \& D$ waste treatment also hinder the use of recycled $C \& D$ waste products. Recycled products and materials are often more expensive than nonrecycled, and therefore, the client is unlikely to be willing to pay for it [29].

Unsupportive regulations, combined with complicated and difficult to achieve standards and specifications, are further reasons that discourage the application of recycled C\&D waste products in construction projects [29,30]. Liu et al. [31] report specific legislation and regulations are the most influential factor in the C\&D waste recycling industry in China, which also affects other important factors. Waste recycling contributes to conservation/preservation of precious land areas through the reduction in opening new landfills and extension of the lifespan of existing landfills. By advocating best practices related to re-use and recycling of $C \& D$ waste and improving the quality of secondary materials enables the construction sector to achieve sustainable outcomes [32,33].

Job creation is a direct advantage of waste recovery [34]. The potential for jobs to be created through a local market is attractive to decision-makers, politicians, and different stakeholders. A study on jobs associated with a circular economy in the UK shows that reuse and recycling jobs would be geographically dispersed across the country while remanufacturing jobs are likely to be more concentrated near existing manufacturing hubs [35]. In Western Australia (WA), it is reported that the development of a vibrant waste industry and local recovery and recycling would deliver three times more jobs than just sending rubbish to landfill. WA also projected that an Energy from Waste (EfW) facility could create 800 job opportunities during construction and 60 full-time jobs during operation [36]. In 2017, Visy Australia, a company involved in resource recovery activities, announced its 10-year expansion plan that will create 5000 manufacturing jobs and 15,000 indirect jobs [37]. Successful recycling is not determined solely by the amount of materials collected but also by the amount processed and reused in new applications. It is a market that is largely influenced by various stakeholders across the supply chain of waste material [38]. While there is a large body of research on stakeholders' behaviours and attitudes for waste minimisation practices [22,28,39-42], there is a little research around stakeholders' perceptions of utilising C\&D waste recycled in the construction industry. The overall finding from studies on waste management attitudes and behaviour shows that while industry supports further recycling it is still not widely adopted. This is due to various reasons such as poor planning [22], a lack of enforceable legislation and financial incentives [28]; a lack of interest from clients, attitudes towards waste minimisation, and a lack of training [40].

Previous studies have shown differences in the perception of stakeholders in using recycled C\&D waste products in construction projects. In 2004, a study in the UK [11] found extremely similar perception of obstacles in using recycled materials. The initial observations reveal that research studies in this field of research only focus on a few stakeholders, which might limit the generalisability and applicability of the findings. Therefore, this research set out to provide an insight into the factors that various stakeholders believe influence the market for recycled $C \& D$ waste products. This research-to the best of the authors' knowledge-is the first review paper that focuses on stakeholder perceptions across the supply chain specific to the utilisation of recycled materials in the construction projects. The guiding research questions of this review study are as follows:

(1) Who are the main stakeholders in the usage of recycled C\&D waste products?

(2) What are the main factors influencing stakeholders' decisions to apply recycled C\&D waste products?

(3) What are the main strategies to improve the application of recycled C\&D waste products in construction projects? 
This review is a part of a larger project (1.75 Creation and Stimulation of End Markets for Construction and Demolition Waste) that aims to create and stimulate the market for recycled C\&D waste products. The project is financially supported by the Australia Sustainable Built Environment National Research Centre.

\section{Methodology}

The study employs a structured literature review to collect data on key stakeholder perceptions of using recycled C\&D waste products. This approach was inspired by 'Preferred Items for Systematic Review Recommendations' (PRISMA) described by Moher et al., [43] and five key phases outlined by Denyer and Tranfield [44]. The goal is to understand how various stakeholders consider the application of recycled C\&D in construction projects, so only those stakeholders that are involved in the C\&D waste material supply chain after it is turned into recycled material were considered. The main search keywords were "recycled materials", "construction waste" and "stakeholders". The three main research engines (i.e., Google Scholar, Web of Science and Scopus) were used to identify relevant research outputs. The following selection criteria were adopted to select studies with the most relevance to the objectives:

(1) Studies published after 2004 to reflect the current conditions of the industry and market;

(2) Studies based on interview/survey or focus group methods with the influential stakeholders;

(3) Studies with a focus on understanding stakeholders' perceptions of and motivations for using recycled C\&D waste products

Given the criteria on an interview, survey and focus group approaches, any studies applying other methods, such as simulation techniques, were excluded.

A meta-search was conducted on literature from 2004 to 2020 using the keywords of recycled materials", "construction waste" and "stakeholders"; this resulted in 71 research outputs which then increased to 93 through the identification of other sources referenced in the initial research outputs. The duplicates were removed and most relevant research for recycled C\&D waste considered. Finally, after removing duplicates, applying the inclusion and exclusion criteria, and additional quality assurance checks, 31 publications were selected for the review which indicates the limited research carried out in this area. The selection process is presented in the PRISMA flow chart in Figure 1. The analysis of the key literature was undertaken in two stages of descriptive analysis and thematic analysis (Sections 3 and 4). The full review protocol was inspired by the systematic literature review approach defined by Denyer and Tranfield [44]. 


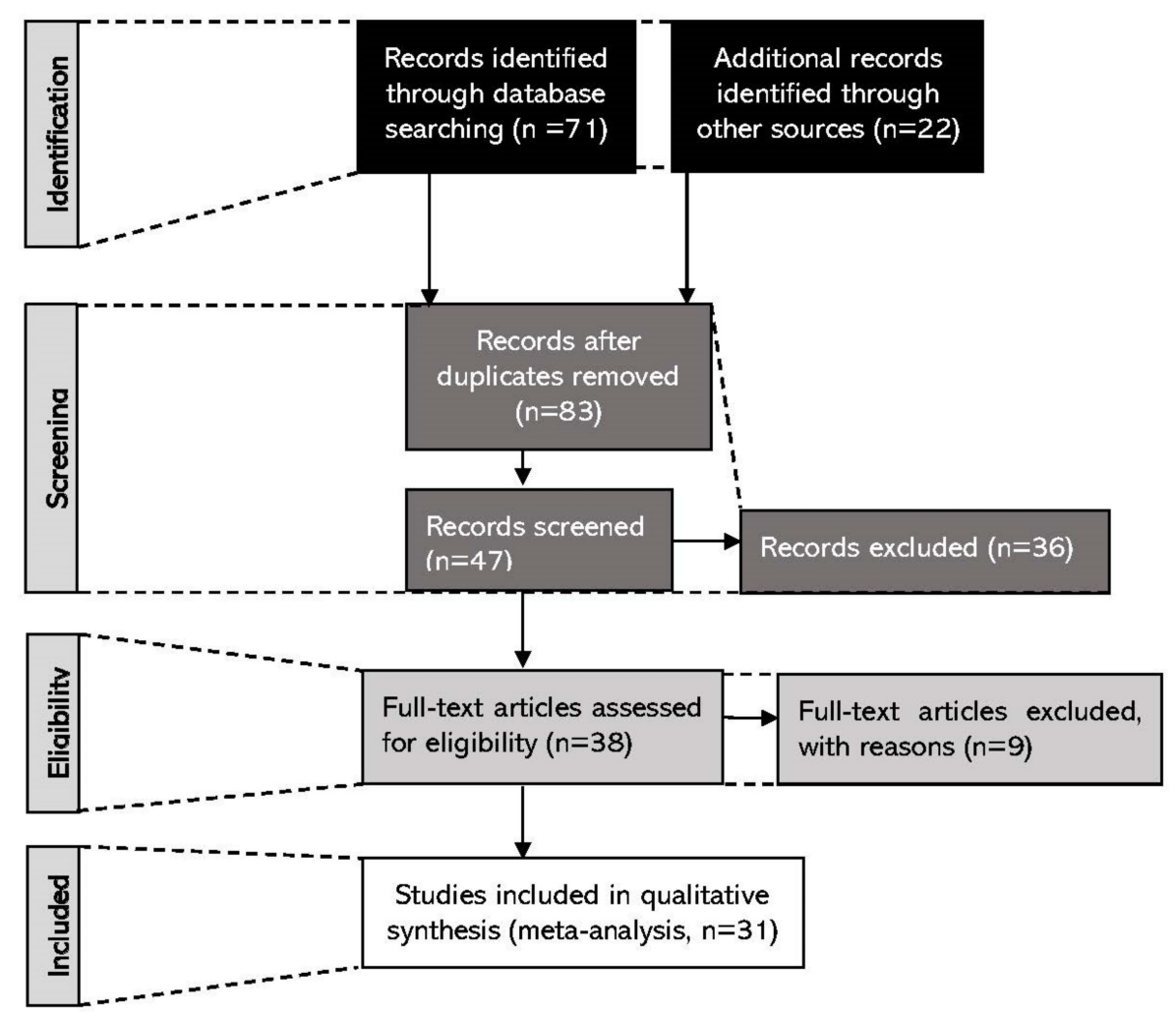

Figure 1. PRISMA flow diagram (adapted from Moher, et al., 2009).

\section{Descriptive Findings}

Figure 2 presents the number of publications related to the topic of research in chronological order between 2004 and 2020. The low number of research outputs, captured in this review study, suggests an urgent need of the investigation on using recycled $C \& D$ waste product. There is a sharp increase from 2014, highlighting the increase in attention over time on the roles and perceptions of stakeholders using recycled C\&D waste products.

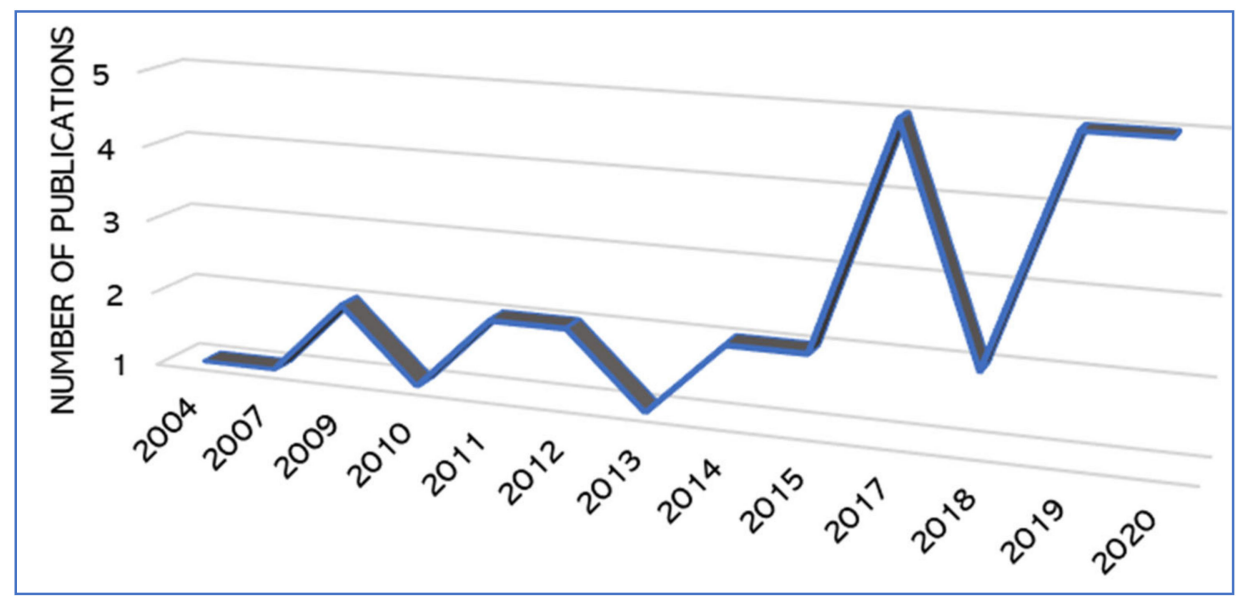

Figure 2. Research outputs published versus year.

In terms of types of research publications, the majority of sources had been published in the form of a journal article and research report. Of the 31 outputs selected for the review, 23 were journal articles whilst 10 were conference papers, reports, and research theses. Many of the journal articles were published in Resources, Conservation and Recycling $(n=7)$, and Journal of Cleaner Production $(n=5)$. When considering the geographic distribution of reviewed publications, a significant proportion of 
publications were from Australia, China, UK and European countries. This is a good indication of the research appetite on recycled C\&D waste products within the global and local contexts.

\section{Thematic Findings and Discussion}

The thematic findings of the structured literature review were categorised under the key themes of: (1) Key stakeholders influencing the use of recycled C\&D waste products; (2) Barriers for using recycled C\&D waste products; and, (3) Enablers to enhance the application of recycled products in the construction industry. These themes are discussed in detail in the following sections.

\subsection{Key Stakeholders Influencing the Use of Recycled CED Waste Products}

To identify the key stakeholders that influence the use of recycled C\&D waste products, the content of relevant previous studies was analysed. A summary of these studies is presented in Table 1 . The literature analysis revealed that there is no general agreement about the main with the most influence on the use of recycled C\&D waste products in literature. Hence, based on the frequency of their appearance in reviewed literature six stakeholder categories were shortlisted. These categories are clients (homeowner/community, $n=14)$, government $(n=18)$ recyclers $(n=11)$, architects $(n=13)$, builders $(n=11)$, and civil/structural engineers $(n=16)$, as visualised in Figure 3 . This study only considered stakeholders who influence the application of recycled content materials when produced. Each of these stakeholder categories is discussed in turn. Previous studies also established that the increased collaboration between stakeholders will lead to increased uptake of using recycled C\&D waste products [45].

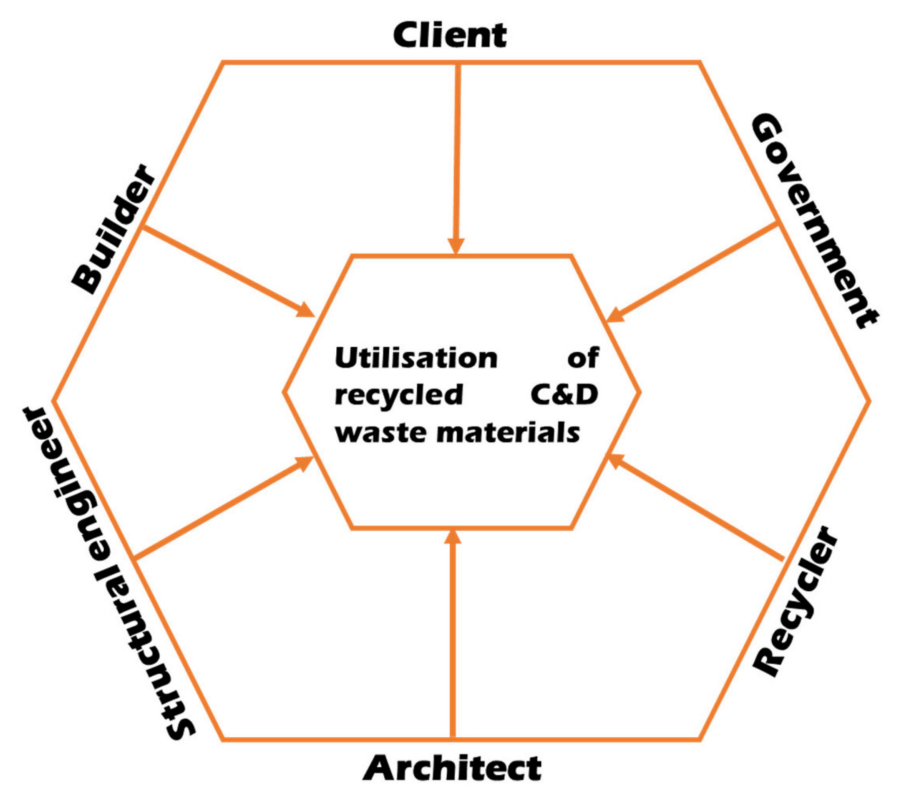

Figure 3. Key stakeholders influencing the use of recycled C\&D waste products.

\subsubsection{Clients}

As built environment end-users of the, clients play a critical role in using recycled products. Business marketing theories consider a client's hesitation to be an important factor in the choice of recycled products. He and Yuan [46] argue that clients might hesitate when facing a decision on choosing either new or recovery products, because consumers' quality perceptions and behaviours towards product selection can be influenced by a set of factors such as product appearance, economic performance and environmental impact. Mahpour [47] report that building users prefer them to be built with new rather than with recycled materials. 
Clients' knowledge and expectations about using recycled products are among the most important criteria for both private and commercial projects, though there is a level of discrepancy. While the more experienced commercial clients clearly judge conventional materials to be technically better than recycled products, private clients have a more balanced weighting regarding technical aspects [30]. Ghaffar et al. [48] report that clients are not interested in recycled C\&D waste products due to the reduction of the product's warranty, meaning that they will require maintenance sooner than a new product. The authors indicate that the saving achieved from using recycled materials is insignificant, such as a $£ 10,000$ saving on a $£ 250$ million job. Table 1 summarises the previous studies in which stakeholders for the application of recycled C\&D waste products were identified.

\subsubsection{Government and Policymakers}

Various level of governments and associated policymakers can support and promote using recycled products in multiple ways, including information sharing, developing technical specifications and policies such as sustainable procurement, creation, and stimulation of the market. Sustainable procurement is a policy approach whereby certain projects are obliged to use recycled products. The results of a survey on policy and/or procurement changes in Australia revealed the top three most effective methods: (1) better and more specification information and knowledge sharing about recycled materials; (2) development of fit-for-purpose standards and specifications to define uses; and, (3) making recycled product mandatory in construction projects [51].

Reports indicate that past governments' actions and policies have discouraged the application of recycled products. For instance, Tam et al. [49] state that local councils and state government in an Australian state disallowed the use of recycled materials in new construction work. In a UK study [48], research participants show that the level of engagement of policymakers with the concept of circular construction is not satisfactory, as they are not able to understand the benefits it could have towards achieving some of the sustainable development goals and combating global challenges such as global warming, climate change and resource scarcity.

\subsubsection{Recyclers (Manufacturers and Suppliers)}

Recyclers face several issues in selling their products on the market including unacceptable contamination, lack of viable market, total cost, availability of technical knowledge and expertise for further process improvements, local availability of equipment and negative perceptions [50]. Ghaffar et al. [48] report that recyclers in the UK are hesitant recover C\&D waste due to limited market opportunities. They also state that recyclers did not have sufficient motivation to innovate in terms of material recovery and processing technologies, as the market does not incentivise them to do so.

\subsubsection{Architects (Designers)}

Architects are at the forefront of applying recycled products in the built environment through creating construction specifications before work starts in consultation with structural engineers. However, previous studies have found that architects rarely specify recycled products [12,52]. A UK study reports that architects consider there to be a lack of adequate information about quality and market availability, negative perceptions from clients, and high cost despite its perceived low quality are the main barriers towards specifying recycled products in their building designs [12]. The results of a survey of 141 architects in Nigeria show that among ten strategies to build a sustainable house the use of recycled materials was rated as the second least preferred option [52]. 
Table 1. Summary of studies conducting research in the field of C\&D waste management.

\begin{tabular}{|c|c|c|c|}
\hline Source & Context of Study/Study Method & Findings & Stakeholders Identified $*$ \\
\hline [31] & $\begin{array}{l}\text { China C\&D waste related stakeholders } \\
\text { Questionnaire survey }\end{array}$ & $\begin{array}{l}\text { The stakeholders in China's CD waste recycling mainly include the government, the CD } \\
\text { waste production units and the } C D \text { waste recycling units. The study did not separate } \\
\text { responses based on the stakeholders. }\end{array}$ & Gov, Rec, Buil \\
\hline [12] & $\begin{array}{l}\text { UK C\&D waste } \\
\text { Interview }\end{array}$ & $\begin{array}{l}\text { The study uncovers a suite of strategies to promote the use of the products including: } \\
\text { allocation of points to the use of recycled products in sustainable design appraisal tools; } \\
\text { governments legislative measures; improved collaboration between designers, contractors } \\
\text { and materials suppliers; contractors involvement at earlier stage of design, improved } \\
\text { education of the professionals about the products; and, the use of tax break to influence the } \\
\text { cost of the products. }\end{array}$ & Arc, Buil, Gov \\
\hline [16] & $\begin{array}{l}\text { US C\&D waste- } \\
\text { Interview }\end{array}$ & $\begin{array}{l}\text { Results indicated that some companies were not aware of the availability, quality of the } \\
\text { materials' performance, cost savings or any other benefits, including environmental benefits. }\end{array}$ & Arc, Rec, CE, SE, Man, WC, Buil \\
\hline$[30]$ & $\begin{array}{l}\text { Switzerland construction's } \\
\text { stakeholders } \\
\text { Interview }\end{array}$ & $\begin{array}{l}\text { The results are based on the key stakeholders' behaviour in structural and civil engineering } \\
\text { phases. While private and commercial clients predominantly preferred conventional } \\
\text { construction materials, the public client chose recycled C\&D waste products over other } \\
\text { alternatives at the structural engineering stage. At the civil engineering phase, only one-third } \\
\text { of projects used recycled C\&D waste products. CEs recommended in } 24-30 \% \text { of cases. To a } \\
\text { large extent, stakeholders make their decisions rationally. }\end{array}$ & Arc, CE, SE, Gov, Cl \\
\hline [49] & $\begin{array}{l}\text { Australia C\&D waste-related } \\
\text { stakeholders } \\
\text { Interview }\end{array}$ & $\begin{array}{l}\text { Landfill tipping fees for disposal of construction and demolition waste in South East } \\
\text { Queensland are low in comparison with other states. Thus, there is little incentive to recycle } \\
\text { waste in lieu of disposal. The cost to transport construction materials made from construction } \\
\text { and demolition waste (as processed at established centralised recycling plants) is relatively } \\
\text { high compared with the cost of using similar virgin materials delivered to the construction } \\
\text { site via traditional commercial channels. Local councils and state government disallow the } \\
\text { use of recycled materials in new construction work (Main Roads-Australia 2006). Recycled } \\
\text { material properties are considered inferior for construction applications. Experience is } \\
\text { lacking in applying proper methods of recycling materials for construction applications. }\end{array}$ & Rec, Buil \\
\hline [50] & $\begin{array}{l}\text { Australia C\&D waste-related } \\
\text { stakeholders } \\
\text { Interview }\end{array}$ & $\begin{array}{l}\text { This guide is to help develop effective markets for materials diverted or derived from the } \\
\text { C\&D waste stream by uncovering opportunities for effective markets. Furthermore, } \\
15 \text { initiatives are presented showing evidence of companies that are profiting and growing } \\
\text { while contributing to a more ecologically sustainable built environment. }\end{array}$ & $\begin{array}{l}\text { Local Government Associations and } \\
\text { associations such as the ARRB Group, } \\
\text { APPA, Institute of Public Works } \\
\text { Engineering Australia to architects, } \\
\text { builders, building inspectors }\end{array}$ \\
\hline
\end{tabular}

* Note: Arc: Architect, Buil: Builder, CE: Civil engineer, Cl: Client, Gov: Government, Man: Manufacturer, Rec: Recycler, SE: Structural engineer. 


\subsubsection{Structural and Civil Engineers}

Structural engineers have a significant responsibility in material, application, and specification decisions. A study conducted in Switzerland [30] found that structural engineers typically adopt conventional materials over recycled products mainly owing to three reasons: unfamiliarity with the objectives of sustainable construction programs (i.e., just focusing on energy issues); their experience and adherence to standards; and their responsibility for the static integrity of a construction project. The last reason makes them liable for the potential damage to end-users and high repair and re-do costs, accounting for their unwillingness to recommend recycled products.

\subsubsection{Builders}

Builders' knowledge and experience in dealing with recycled products are central to increased product usage. Basically, recycled material properties are considered inferior and are difficult for construction applications [49,51]. The cost to transport construction materials made from construction and demolition waste (as processed at established centralised recycling plants) is relatively high compared with the cost of using similar virgin materials delivered to the construction site via traditional commercial channels [49].

\subsection{Barriers for Using Recycled CED Waste Products}

The uptake of practices related to using recycling C\&D products are still limited and continue to have detrimental impacts on the environment [53]. The main barriers towards using recycled products in the construction industry have been identified from previous studies (Table 2). The following section provides an explanation of how these factors have hindered the application of recycled products in construction projects.

Table 2. The main barriers to the use of recycled materials from stakeholders' perspectives discovered in previous studies.

\begin{tabular}{ccc}
\hline No & Barrier & Short Description \\
\hline 1 & Increased costs of energy and transport & $\begin{array}{c}\text { Sometimes recycled products are costlier than } \\
\text { raw materials. }\end{array}$ \\
\hline 2 & Lack knowledge on recycled products & $\begin{array}{c}\text { Unfamiliarity with recycled products limited } \\
\text { their application in construction projects. }\end{array}$ \\
\hline 3 & Limited technologies for waste recovery & $\begin{array}{c}\text { Limited technologies in the waste recovery } \\
\text { industry resulted in poor quality and expensive } \\
\text { recycled products. }\end{array}$ \\
\hline 5 & Low quality, contamination, and & $\begin{array}{c}\text { Less than expected quality hinders the wide } \\
\text { reduced performance }\end{array}$ \\
\hline 6 & Lack of market availability of the products & $\begin{array}{c}\text { Uncertainty about market discourages the } \\
\text { production of quality second-hand materials. }\end{array}$ \\
\hline 7 & $\begin{array}{r}\text { Limitations caused by specifications, } \\
\text { standards and permits }\end{array}$ & $\begin{array}{c}\text { Specifications and standards have both positive } \\
\text { and negative impact on the recycled } \\
\text { product's market. }\end{array}$ \\
\hline
\end{tabular}

\subsubsection{Increase in Energy and Transport Costs}

Cost is considered to be one of the main barriers towards using recycled C\&D waste materials in the construction industry [12]. Several studies indicate that recycled products are costlier than conventional materials [24,54-56]. A few reasons contribute to higher costs in recycled C\&D waste materials including longer transport distance [57], industrial waste sorting procedures [24], increased 
energy requirements for recycling, landfill levy for residual waste and high capital costs for recycling facilities [9] and equipment [41,44]. In some circumstances use of recycled materials are reported to be less expensive than fresh materials $[50,58]$. However, if waste producers and recyclers are willing to work collaboratively, it can lead to a win-win situation for both parties [59].

\subsubsection{Limited Knowledge on Recycled Products}

There is solid evidence that a lack of knowledge of the various characteristics of recycled waste is a factor that diminishes the willingness to use them in the construction industry. A lack of awareness and knowledge leads to negative market demand for recycled products. This could also lead to a negative perception of used materials, final product quality and price in recycled products from the end-users [16,50]. Marketplaces for re-used and recycled material are yet to me mainstream and there is still limited development of knowledge and practical impacts [54]. The limited communication between key stakeholders such as contractors and recyclers and "wait and see" attitude are also other factors affecting the limited knowledge on recycled products [24].

\subsubsection{Limited Technologies for Waste Recovery}

Technologies play an important role in safe and effective waste recovery. Limited technological advances and associated high capital costs in the waste recovery sector historically hinder manufacturing commercially competitive products [16,48]. Limited education on emerging waste recover technologies, lack of investment on waste management technologies [24], and limited incentives for private investment in technology [46] are key reasons affecting the uptake of recycled C\&D product use [43].

\subsubsection{Low Quality and Reduced Performance}

Previous research studies indicate that construction industry stakeholders face issues such as quality, contamination and unacceptable performance when choosing recycled products over conventional materials [16,50]. Lack of technologies support, such as resources, training [24], limited competent staff and expertise and lack of benchmarking tool [24], lack of systematic decontamination procedures [8] are key reasons affecting the quality and reduced performance of recycled C\&D waste products. As there is no assurance of maintaining the same quality and performance as virgin resources in the recycled product and there is a critical need for defining standards, producers and training staff members [24].

\subsubsection{Lack of Market Availability of the Products}

The viable market has a direct mutual relationship with further using recycled products [31]. When there is an established market for recycled products, the economy of scale assists with further investment in recycling facilities, resulting in lower total cost, higher quality, and less contamination $[12,51]$. The imbalance of supply and demand for recycled products creates a narrow window of opportunity to trade recycled C\&D products [9]. A study in Australia on recycled PVC products application reports that the cost of recycled material is the same as virgin material and recommended that the industry needs greater scale or a higher value for PVC to incentivise more PVC recycling [50]. Once these results are achieved, more industry stakeholders will be persuaded to buy and use recycled materials in construction projects. Market availability is underpinned by several factors including effective supply chain, properly designed landfill levy, government incentives and subsidies, and finding new applications outside of the construction industry [54].

\subsubsection{Limitations Caused by Specifications, Standards and Permits}

There is an ongoing debate within the waste management and resource recovery industry about the role of specifications, standards and permits in promoting the application of recycled products in the construction industry $[51,60]$. If the organisations need to provide indemnities, operate trials, 
or accept risk, these also creates and additional layer of complexity which may become impediments for recycling C\&D waste products [54]. On the one hand, specifications and standards determine the quality of materials recycled, giving peace of mind to stakeholders to use these materials. On the other hand, many recyclers indicate that complicated and difficult to meet specifications and standards are a significant hindrance in selling recycled products to the market.

\subsubsection{Limited Acceptability and Negative Perceptions (Public and the Industry)}

Due to various factors, such as a lack of knowledge and a view of the products as unconventional, there is a negative perception among construction industry stakeholders towards using recycled products [54]. Different stakeholder groups may have different perceptions [61]. These perceptions are changing as field trials show how to use these materials to their optimum performance and as virgin resources become scarcer [50].This highlights the critical need for need for prototyping during design stages to test acceptability [54].

\subsection{Enablers to Enhance the Application of Recycled Products in the Construction Industry}

Five clusters of enablers have been identified that can assist key stakeholders to advocate the use of recycled materials in the construction industry.

\subsubsection{Increase Community Awareness and Education on Recycled Products}

Access to information and the education of construction experts are the two points of leverage for increasing the application of recycled products [30]. Therefore, bolstering efforts to inform stakeholders about the technical properties and environmental performance (primarily awarding authorities), and existing law and standards, is required. Furthermore, the distribution of more data, better documentation and reports about reference buildings assist with increasing engineers' experience with recycled products. In addition, the scientific community needs to make a more significant effort to convey the acquired knowledge to the professionals.

\subsubsection{Develop Supportive Regulations, Policies, and Specifications}

The government should prioritise the task of improving specific legislation and regulations, with a focus on establishing the mandatory degree of normative standards. Notably, design codes should highlight the environmental aspects of the construction and give designers more flexibility in material sourcing leading to an increased usage of recycled products [29]. Detailed specifications should also be developed in the form of application-specific quality standards for different recycled products as another option to increase the demand for such products [30]. The introduction of mandatory policies (unified, stakeholder oriented policies) [24,62], such as sustainable procurement to meet specific reuse/recycling targets, more purchasing power and grants that are offered to companies to help initiate recycling locally [63] would encourage both recyclers and builders to invest in waste management solutions [48].

\subsubsection{Facilitate Sustainability Programs}

Another promising route is the implementation of sustainability programs that suggest the use of recycled products in construction projects. Some reports $[64,65]$ have demonstrated that running these programs leads to further adoption of recycled products in the construction industry. However, there is evidence proving otherwise [66]. Among others, it seems that the design of rating systems, developers' biases, and lack of incentives to motive end-users are most influential reasons for their ineffectiveness. Furthermore, scholarly and political engagement with business practice are urgently needed to facilitate sustainability programs [67]. 


\subsubsection{Promote Product Certification}

A product certification that is awarded following material testing, plus quality control, can increase the adoption of recycled materials in the construction industry. As different supply sources will cause variation in quality, stricter quality controls for recycled materials are required [49]. A government agency should be established to control the quality and production of these materials. Guidance on clear technical specifications or standards on the use of recycled aggregate for structural applications will enable recyclers to produce adhere to industry standards [24].

\subsubsection{Advocate Targeted Technologies and Innovative Practice}

The waste management and resource recovery industry should embrace new technologies and innovation. Technological advances help recycled materials producers meet market demands through products having reasonable price and quality. Notably, governments, as the main stakeholder responsible for protecting the environment, should support the industry by providing a fund to invest in technologies and innovation.

\subsection{An Emergent Model for Enablers and Barriers}

Based on the five categories of barriers (Section 4.2) and seven categories of enablers (Section 4.3) derived from the analysed literature the authors propose an emergent model (Figure 4) on barriers and enablers for using recycled C\&D waste products. Starting with the left-hand side, the seven key barriers that influences the key stakeholders (Section 4.1) ability to utilise C\&D waste the application of recycled products in the construction industry. These barriers includes: increase in energy and transport costs; lack knowledge on recycled products; limited of technologies for waste recovery; low quality and reduced performance; lack of market availability of the products; limitations caused by specifications, standards and permits; and limited acceptability and negative perceptions. The right-hand side of the model presents five enablers that would help stakeholders to improve applications of recycled products. These enablers cover increase community awareness and education on recycled products; develop supportive regulations, policies, and specifications; facilitate sustainability programs; promote product certification and advocate targeted technologies and innovative practice.

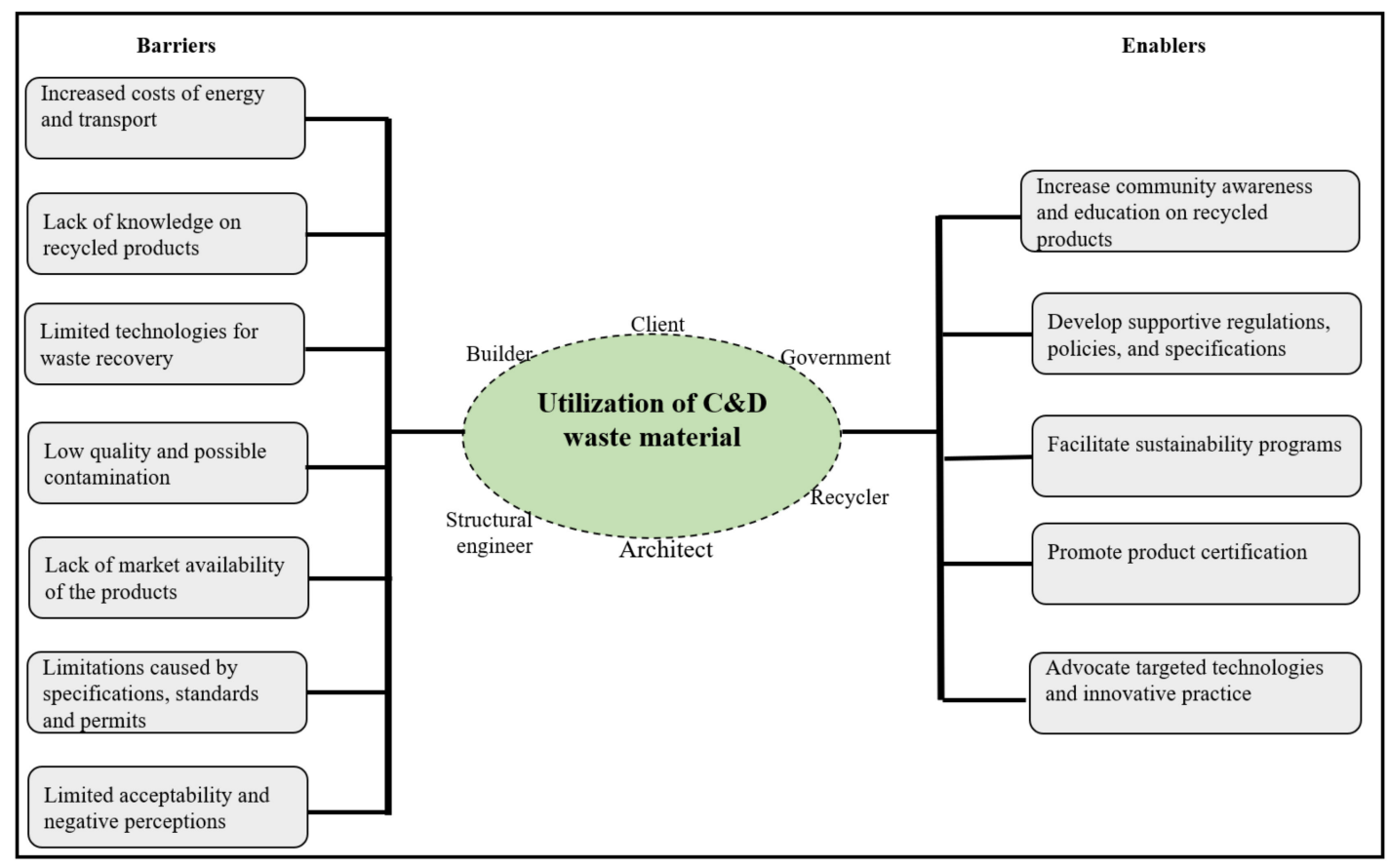

Figure 4. Emergent model on barriers and enablers for using recycled C\&D waste products. 
The model conceptually indicates how successfully addressing the barriers and amplifying the enablers can enhance the application of recycled products in the construction industry.

\section{Conclusions}

This study reviewed key references on the use of recycled materials in construction projects. A systematic literature review examined stakeholders' considerations in using these products and the perceived barriers to their use. The key finding is that there is little research carried out to date to cover the use of recycled products in the construction industry after processing C\&D waste, most studies have focused on strategies as to reduce or recycled this waste stream. This study reveals six key categories of stakeholders who can influence the decision on using recycled product in the industry: client, government, recycler, architect, civil/structural engineer, and builder. The study also provides discussion on how their perceptions, decision and behaviour influence the use of recycled C\&D waste products. Subsequently, the authors present an emergent enablers and barriers for recycled C\&D waste products model and provides commentary on how their perceptions, decision and behaviour influence the use of recycled C\&D waste products. This study contributes to the body of knowledge with insights into the factors that various stakeholders believe influence the market for recycled C\&D waste products and a reference point for authorities to consider the behavioural insights for policy reform. While the authors acknowledge the limitations of the sampling criteria this research creates an opportunity for future inquiries and advances in the field. While it is important to identify the key stakeholders influencing the use of recycled C\&D waste products, the critical next step would be to test and validate the enablers and barriers model and further examine the factors influencing stakeholders' decisions to apply recycled $C \& D$ waste products to enable a closed loop through waste recycling.

Funding: This research was funded by the Australian Sustainable Built Environment National Research Centre.

Conflicts of Interest: The authors declare no conflict of interest.

\section{References}

1. Islam, R.; Nazifa, T.H.; Yuniarto, A.; Uddin, A.S.; Salmiati, S.; Shahid, S. An empirical study of construction and demolition waste generation and implication of recycling. Waste Manag. 2019, 95, 10-21. [CrossRef]

2. Tang, Z.; Li, W.; Tam, V.W.; Xue, C. Advanced progress in recycling municipal and construction solid wastes for manufacturing sustainable construction materials. Resour. Conserv. Recycl. X 2020, 6, 100036. [CrossRef]

3. Yeheyis, M.; Hewage, K.; Alam, M.S.; Eskicioglu, C.; Sadiq, R. An overview of construction and demolition waste management in Canada: A lifecycle analysis approach to sustainability. Clean Technol. Environ. Policy 2013, 15, 81-91. [CrossRef]

4. Ulubeyli, S.; Kazaz, A.; Arslan, V. Construction and Demolition Waste Recycling Plants Revisited: Management Issues. Procedia Eng. 2017, 172, 1190-1197. [CrossRef]

5. Balador, Z.; Gjerde, M.; Isaacs, N. Influential Factors on Using Reclaimed and Recycled Building Materials. In Sustainability in Energy and Buildings; Howlett, R., Littlewood, J., Capozzoli, A., Jain, L., Eds.; Springer: Singapore, 2020; pp. 37-47.

6. Caldera, H.T.S.; Desha, C.; Dawes, L. Transforming manufacturing to be 'good for planet and people', through enabling lean and green thinking in small and medium-sized enterprises. Sustain. Earth 2019, 2, 4. [CrossRef]

7. Bocken, N.M.P.; De Pauw, I.; Bakker, C.; Van Der Grinten, B. Product design and business model strategies for a circular economy. J. Ind. Prod. Eng. 2016, 33, 308-320. [CrossRef]

8. Sánchez, I.G.; Lauritzen, E.K. Integrated Decontamination and Rehabilitation of Buildings, Structures and Materials in Urban Renewal-a European Project for a Sustainable City Concept. In Proceedings of the International RILEM Conference on the Use of Recycled Materials in Buildings and Structures, Barcelona, Spain, 8-11 November 2004.

9. Wang, J.; Li, Z.; Tam, V.W. Critical factors in effective construction waste minimization at the design stage: A Shenzhen case study, China. Resour. Conserv. Recycl. 2014, 82, 1-7. [CrossRef] 
10. Shooshtarian, S.; Maqsood, T.; Wong, S.P.; Yang, J.R.; Khalfan, M. Review of Waste Strategy Documents in Australia: Analysis of Strategies for Construction and Demolition Waste. Int. J. Environ. Technol. Manag. 2020, 23, 1-21. [CrossRef]

11. Chick, A.; Micklethwaite, P. Specifying recycled: Understanding UK architects' and designers' practices and experience. Des. Stud. 2004, 25, 251-273. [CrossRef]

12. Oyedele, L.O.; Ajayi, S.; Kadiri, K.O. Use of recycled products in UK construction industry: An empirical investigation into critical impediments and strategies for improvement. Resour. Conserv. Recycl. 2014, 93, 23-31. [CrossRef]

13. Herrador, R.; Pérez, P.; Garach, L.; Ordóñez, J. Use of Recycled Construction and Demolition Waste Aggregate for Road Course Surfacing. J. Transp. Eng. 2012, 138, 182-190. [CrossRef]

14. Al-Sari, M.; Al-Khatib, I.; Avraamides, M.; Fatta-Kassinos, D. A study on the attitudes and behavioural influence of construction waste management in occupied Palestinian territory. Waste Manag. Res. 2012, 30, 122-136. [CrossRef]

15. Wang, T.; Wang, J.; Wu, P.; Wang, J.; He, Q.; Wang, X. Estimating the environmental costs and benefits of demolition waste using life cycle assessment and willingness-to-pay: A case study in Shenzhen. J. Clean. Prod. 2018, 172, 14-26. [CrossRef]

16. Bolden, J.; Abu-Lebdeh, T.; Fini, E. Utilization of Recycled and Waste Materials in Various Construction Applications. Am. J. Environ. Sci. 2013, 9, 14-24. [CrossRef]

17. Lee, J.; Edil, T.B.; Benson, C.H.; Tinjum, J.M. Building Environmentally and Economically Sustainable Transportation Infrastructure: Green Highway Rating System. J. Constr. Eng. Manag. 2013, 139, 4013006. [CrossRef]

18. Tahmoorian, F.; Bracken, R.; Wheatley, M.; Yeaman, J. Life Cycle Assessment of Hot Mix Asphalt Containing Recycled Materials: Case Study in Australia. In Airfield and Highway Pavements; American Society of Civil Engineers: Reston, VA, USA, 2019.

19. Ghisellini, P.; Ripa, M.; Ulgiati, S. Exploring environmental and economic costs and benefits of a circular economy approach to the construction and demolition sector. A literature review. J. Clean. Prod. 2018, 178, 618-643. [CrossRef]

20. Shooshtarian, S.; Maqsood, T.; Khalfan, M.; Yang, R.J.; Wong, P.S.P. Landfill Levy Imposition on Construction and Demolition Waste: Australian Stakeholders' Perceptions. Sustainability 2020, 12, 4496. [CrossRef]

21. Rameezdeen, R.; Chileshe, N.; Hosseini, M.; Lehmann, S. A qualitative examination of major barriers in implementation of reverse logistics within the South Australian construction sector. Int. J. Constr. Manag. 2015, 16, 1-12. [CrossRef]

22. Tam, V.W.; Le, K.N.; Wang, C.; Illankoon, I.C.S. Practitioners Recycling Attitude and Behaviour in the Australian Construction Industry. Sustainability 2018, 10, 1212. [CrossRef]

23. Gao, W.; Ariyama, T.; Ojima, T.; Meier, A. Energy impacts of recycling disassembly material in residential buildings. Energy Build. 2001, 33, 553-562. [CrossRef]

24. Tam, V.W. Comparing the implementation of concrete recycling in the Australian and Japanese construction industries. J. Clean. Prod. 2009, 17, 688-702. [CrossRef]

25. Hossain, U.; Poon, C.S.; Lo, I.M.; Cheng, J.C. Comparative environmental evaluation of aggregate production from recycled waste materials and virgin sources by LCA. Resour. Conserv. Recycl. 2016, 109, 67-77. [CrossRef]

26. Sustainable Aggregates South Australia. Recycled Aggregates Bring Carbon Reduction Benefits Recycled Aggregates Bring Carbon Reduction Benefits; Sustainable Aggregates South Australia: Adelaide, Australia, 2010.

27. Kuittinen, M. Does the use of recycled concrete lower the carbon footprint in humanitarian construction? Int. J. Disaster Resil. Built Environ. 2016, 7, 472-488. [CrossRef]

28. Udawatta, N.; Zuo, J.; Chiveralls, K.; Zillante, G. Attitudinal and behavioural approaches to improving waste management on construction projects in Australia: Benefits and limitations. Int. J. Constr. Manag. 2015, 15, 137-147. [CrossRef]

29. Park, J.; Tucker, R. Overcoming barriers to the reuse of construction waste material in Australia: A review of the literature. Int. J. Constr. Manag. 2016, 17, 228-237. [CrossRef]

30. Knoeri, C.; Binder, C.R.; Althaus, H.-J. Decisions on recycling: Construction stakeholders' decisions regarding recycled mineral construction materials. Resour. Conserv. Recycl. 2011, 55, 1039-1050. [CrossRef]

31. Liu, H.; Long, H.; Li, X. Identification of critical factors in construction and demolition waste recycling by the grey-DEMATEL approach: A Chinese perspective. Environ. Sci. Pollut. Res. 2020, 27, 8507-8525. [CrossRef] 
32. Gálvez-Martos, J.-L.; Styles, D.; Schoenberger, H.; Zeschmar-Lahl, B. Construction and demolition waste best management practice in Europe. Resour. Conserv. Recycl. 2018, 136, 166-178. [CrossRef]

33. Sormunen, P.; Kärki, T. Recycled construction and demolition waste as a possible source of materials for composite manufacturing. J. Build. Eng. 2019, 24, 100742. [CrossRef]

34. Shooshtarian, S.; Maqsood, T.; Wong, P.; Khalfan, M.; Yang, R. Review of energy recovery from construction and demolition waste in Australia. J. Constr. Eng. Manag. Innov. 2019, 2, 112-130. [CrossRef]

35. Morgan, J.; Mitchell, P. Opportunities to Tackle Britain's Labour Market Challenges through Growth in the Circular Economy; Green Alliance: London, UK, 2015.

36. Government of Western Australia. A Liveable Environment: Ensuring a Sustainable Future by Linking Homes to Transport, Conserving Land and Reducing Waste; Government of Western Australia: Perth, WA, Australia, 2019.

37. Pratt, A. Visy Chairman Anthony Pratt Announces $\$ 2$ Billion Investment Program to Create 5000 Jobs. Appita Technol. Innov. Manuf. Environ. 2017, 70, 204.

38. Shooshtarian, S.; Maqsood, T.; Wong, P.S.P.; Khalfan, M.; Yang, R.J.; RMIT University. Market development for construction and demolition waste stream in Australia. J. Constr. Eng. Manag. Innov. 2020, 3, 220-231.

39. Teo, M.M.M.; Loosemore, M.; Masosszeky, M.; Karim, K. Operatives Attitudes Towards Waste on a Construction Project. In Proceedings of the 16th Annual ARCOM Conference, Glasgow, UK, 1 September 2000.

40. Osmani, M.; Glass, J.; Price, A.D. Architects' perspectives on construction waste reduction by design. Waste Manag. 2008, 28, 1147-1158. [CrossRef] [PubMed]

41. Begum, R.A.; Satari, S.K.; Pereira, J.J. Waste Generation and Recycling: Comparison of Conventional and Industrialized Building Systems. Am. J. Environ. Sci. 2010, 6, 383-388. [CrossRef]

42. Forghani, R.; Sher, W.; Kanjanabootra, S.; Totoev, Y. The Attitudes of Demolition Contractors to Reusing Building Components: A Study in New South Wales, Australia. Eur. J. Sustain. Dev. 2018, 7, 364-370. [CrossRef]

43. Moher, D.; Liberati, A.; Tetzlaff, J.; Altman, D.G.; Prisma Group. Preferred Reporting Items for Systematic Reviews and Meta-Analyses: The Prisma Statement. PLoS Med. 2009, 6, e1000097. [CrossRef]

44. Denyer, D.; Tranfield, D. Producing a Systematic Review. In The Sage Handbook of Organizational Research Methods; Buchanan, D.A., Bryman, A., Eds.; Sage Publications: Thousand Oaks, CA, USA, 2009.

45. Jiménez-Rivero, A.; García-Navarro, J. Exploring factors influencing post-consumer gypsum recycling and landfilling in the European Union. Resour. Conserv. Recycl. 2017, 116, 116-123. [CrossRef]

46. He, L.; Yuan, H. Investigation of construction waste recycling decisions by considering consumers' quality perceptions. J. Clean. Prod. 2020, 259, 120928. [CrossRef]

47. Mahpour, A. Prioritizing barriers to adopt circular economy in construction and demolition waste management. Resour. Conserv. Recycl. 2018, 134, 216-227. [CrossRef]

48. Ghaffar, S.H.; Burman, M.; Braimah, N. Pathways to circular construction: An integrated management of construction and demolition waste for resource recovery. J. Clean. Prod. 2020, 244, 118710. [CrossRef]

49. Tam, V.W.; Kotrayothar, D.; Loo, Y.-C. On the prevailing construction waste recycling practices: A South East Queensland study. Waste Manag. Res. 2009, 27, 167-174. [CrossRef]

50. Edge Environment Pty. Construction and Demolition Waste Guide-Recycling and Re-Use across the Supply Chain; Edge Environment Pty: Manly, NSW, Australia, 2012.

51. Government of Western Australia. Expanding Reuse Opportunities for Recycled Construction Materials; Government of Western Australia: Perth, WA, Australia, 2020.

52. Fulani, O.; Ukwunna, C.; Ukaegbu, C.; Abraham, A.; Adaramola, A.; Akande, Q. Investigating the Regenerative Architectural Concepts: Principles and Practices of Selected Architects in Lagos, Nigeria. Futo J. Ser. 2019, 5, 266-277.

53. Umar, U.A.; Shafiq, N.; Malakahmad, A.; Nuruddin, M.F.; Khamidi, M.F. A review on adoption of novel techniques in construction waste management and policy. J. Mater. Cycles Waste Manag. 2017, 19, 1361-1373. [CrossRef]

54. Colin, R. Systems for Reuse, Repurposing and Upcycling of Existing Building Components. Ph.D. Thesis, University College London, London, UK, 2019.

55. Dunant, C.F.; Drewniok, M.P.; Sansom, M.; Corbey, S.; Allwood, J.M.; Cullen, J.M. Real and perceived barriers to steel reuse across the UK construction value chain. Resour. Conserv. Recycl. 2017, 126, 118-131. [CrossRef] 
56. Zou, P.; Hardy, R.; Yang, R. Barriers to Building and Construction Waste Reduction, Reuse and Recycling: A Case Study of the Australian Capital Region. In Proceedings of the Building Today-Saving Tomorrow: Sustainability in Construction and Deconstruction Conference, Auckland, New Zealand, 15-17 July 2015.

57. Hiete, M.; Stengel, J.; Ludwig, J.; Schultmann, F. Matching construction and demolition waste supply to recycling demand: A regional management chain model. Build. Res. Inf. 2011, 39, 333-351. [CrossRef]

58. Sustainability Victoria. Market Summary-Recycled Brick, Stone and Concrete. In Fact Sheet; Sustainability Victoria: Melbourne, Australia, 2015.

59. Liu, J.; Nie, J.; Yuan, H. Interactive decisions of the waste producer and the recycler in construction waste recycling. J. Clean. Prod. 2020, 256, 120403. [CrossRef]

60. Spiegel, R.; Meadows, D. Green Building Materials: A Guide to Product Selection and Specification; John Wiley \& Sons: Hoboken, NJ, USA, 2010.

61. Henry, M.; Kato, Y. Perspectives on Sustainable Practice and Materials in the Japanese Concrete Industry. J. Mater. Civ. Eng. 2012, 24, 275-288. [CrossRef]

62. Mak, T.M.; Yu, I.K.; Wang, L.; Hsu, S.-C.; Tsang, D.C.W.; Li, C.; Yeung, T.L.; Zhang, R.; Poon, C.S. Extended theory of planned behaviour for promoting construction waste recycling in Hong Kong. Waste Manag. 2019, 83, 161-170. [CrossRef]

63. Huang, Y.; Bird, R.N.; Heidrich, O. A review of the use of recycled solid waste materials in asphalt pavements. Resour. Conserv. Recycl. 2007, 52, 58-73. [CrossRef]

64. Eisenstein, W.; Fuertes, G.; Kaam, S.; Seigel, K.; Arens, E.; Mozingo, L. Climate Co-Benefits of Green Building Standards: Water, Waste and Transportation. Build. Res. Inf. 2017, 45, 828-844. [CrossRef]

65. Shooshtarian, S.; Maqsood, T.; Wong, S.P.; Malik, K.; Yang, R. Green Construction and Construction and Demolition Waste Management in Australia. In Proceedings of the 43rd AUBEA Conference: Built to Thrive: Creating Buildings and Cities That Support Individual Well-Being and Community Prosperity, Noosa, Australia, 6-8 November 2019.

66. Lu, W.; Chi, B.; Bao, Z.; Zetkulic, A. Evaluating the effects of green building on construction waste management: A comparative study of three green building rating systems. Build. Environ. 2019, 155, 247-256. [CrossRef]

67. Leipold, S.; Petit-Boix, A. The circular economy and the bio-based sector-Perspectives of European and German stakeholders. J. Clean. Prod. 2018, 201, 1125-1137. [CrossRef]

Publisher's Note: MDPI stays neutral with regard to jurisdictional claims in published maps and institutional affiliations.

(C) 2020 by the authors. Licensee MDPI, Basel, Switzerland. This article is an open access article distributed under the terms and conditions of the Creative Commons Attribution (CC BY) license (http://creativecommons.org/licenses/by/4.0/). 